\title{
REVIEIVS
}

\section{THE NEW TESTAMENT}

The New Testament Documents thetr ortgin and tarly history By George Milligan, D D (Macmillan \& Co, Igr3)

Prof Fs4OR Milligan, who has given proof of his exegetical capacity in an admirable commentary on the Epistles to the Thessalonians, here takes up the rôle of a lecturer who is addressing an audience which is educated and intelligent rather than expert or critical But this is not to say that the present volume shtws any falling off in the fullness of knowledge and exactness in detall which were manifested in the earher volume The Croall Lectures were delivered in Igi I, and the interval between their delivery and their publication has given Dr Milligan the opportunity of thoroughly revising the text and adding a valuable appendix of notes

The book, however, is far from being of the nature of a compendium or students' manual 'Written in a singularly clear style, printed in a noble type and with an accuracy which reflects credit upon the Glasgow University Press, and illustrated by numerous photographs of papyri and other MSS, this volume will appeal to hundreds of educated men and women who are not professed students of the New Testament, and would be repelled by the technicalities of the ordinary handbook In The Nere Testament Documents the layman has access to a review, at once attractive and trustworthy, of the most recint information upon a fascinating subject At the same time the nceds of the student have not been overlooked, the foot-notes and appendix throw open to him wide ficlds of research, if he has a mind to pursue any of the topics which the lecturcr has been compelled to touch but lightly in the text

It was to be expected that Dr Milligan, who shares with Dr J. H. Moulton the honour of having called attention in England to the importance of the papyri for the lexicography and grammar of New Testament Greek, would give prominence to this new and growing source of knowledge, and no part of his book will be read with nore interest than the chapters in which he deals with this subject. His conclusions are expresstd with great moderation, thus he writes (p.49) -

'In the not unnatural recorl from the old position of treating the 
Greek of the New Testament as an isolated language, a tendency has shewn itself in various quarters to lose sight of certain distinctive features by which it is none the less marked, and which, notwithstanding all the linguistic and stylistic parallels that have been discovered, impart a character of its own to the language of our New Testament writıngs'

Again, it is refreshing to read ( $\left.p 6_{7} f\right)-$

'Many passagts, especially in the more literary parts of the New Testament, can be adduced where only by a close observance of the distinctions of tense and case construction can the wrters' full meaning be grasped,

The last remark safeguards some of the best work of the last generation from being sacrificed to a too hasty induction from our new knowledge Simlarly, our author refuses to follow Dessmann's sweeping affirmation that the Epistles of St Paul are 'not literary', 'not epistles', mantamıng that 'St Paul stands midway between the literary and nonliterary writers of his day', and that 'when, to meet the special circumstances in which he found himself, St Paul struck out this happy combination of the letter with the epistle he invented a form of composition which in its every line bears witness to the commanding personality and gentus of its author' ( $p p$ 95, $106 \mathrm{f}$ ) The same capacity for holding the balance between extreme opmions shews itself when Dr Milligan proceeds to speak of the interpretative character of the fourth Gospel He points out that 'only as springing from and growing out of the soll of historic fact does the Johannme conception of Christ become for a moment possible', and that 'in certain particulars where he (St John) differs from the Synoptists it is apparently they who require to be corrected by him, and not he by them' (p $\mathrm{J}_{57}$ ) With like good judgement Dr Milligan is proof against the temptation to scize upon a mere conjecture and turn it into a fact Thus ( $\begin{aligned} & p_{1} \\ & \text { 8 }\end{aligned}$ he seems to incline to the theory that a leaf has been lost at the beginning of Hebrews, but this suggestion is at once dismissed with the remark that there is 'absolutely no direct evidence for it', and he proceeds to deal with facts as they are

The additional notes contain much uscful material, if there is little in them that is new, they bring together the most necessary documents and references in a serviccable form Thus note $A$ supplies a list of books for the study of the Greek papyri, note I) enumerates New Testament texts on papyrus, note $\mathrm{N}$ is a short but valuable biblography of recent literature on the New Testament canon Other notes minister to the wants of the younger student and the gencral reader by giving at length certain illustratıve texts, such as the onginal of the Muratorian canon, and the Cospel of Peter, and a few pertınent extracts from Paplac, Irenacus, Athanasius, and Dionysius of Alexandria. 
Dr Milligan's present work does not perhaps contribute much to the knowledge of his subject, but it admirably fulfils the purpose for which it was written, and will help to create an intelligent intcrest in the results of an important branch of New Testament study

H B SWET

John Baptzst and his relation to Jesus By Alban Biakiston, M A. (J \& J Bennett, Ltd, Century Press, London, 19 1 2 )

As regards the ordinary instructed Bible reader there is certainly room for a work which essays to rescue the Baptist from his traditional position of entire subordination to Jesus, and a welcome should await it from the 'students of Christian origins' to whom a somewhat venturesome allusion is made in the preface

The book is quite well arranged Industrious in his research, Mr Blakiston has manifestly been at great pains with the discussion of material and presentment of results There is much good matter in his pages, while special interest attaches to the closing chapter, which offers a sort of impressionist biography of 'the strong man' who has allowed 'free rein to his unhappy dubiety' Albeit prophet of the new, John was himself of the old dispensation, he 'belonged body and soul to that which was destined to die out content to retain his old methods, to live in the past, and to forego that association with Jesus which might have brought him new light' As it was, 'victım of the preposscssions which defined for him the nature of the Messiah's office and work', and carrying his great error to the grave with him, he rushed to a self-invited fate Comet-like had been his career. 'strange and pathetic as any we read of in the whole range of history It is added Perhaps he is not lost to us in reality for as a comet is now and again captured by the force of the attraction it has once felt, so may the Baptist, after a long orbit in the outer darkness, once more respond to the Divine call, and come to shelter himself in the life-grving rays of the Sun of Righteousness'

Mr Blakıston has not exactly rediscovered John That he brings any real contribution to the stock of knowledge may be doubted. it 1s, further, not altogether likely that scholarship will at once identify the real John with the commanding yet misguided personage of his conception His exegesis is not always convincing nor his ground too firm, the occasional mixed metaphor is a blemish, conjecture can cease to be plausible to become pure romance how in the world can the author know that 'Jesus and the Baptist met, solitary by the water-side, as the darkness drew on' and that 'in the darkness they parted '? There is 